\title{
Alert for Consumption of Dorema aucheri: an Edible Medicinal Plant of Iran
}

\author{
Eftekhari M (Ph.D.) ${ }^{1,2}$, Oskou F (Pharm.D.) ${ }^{1}$, Tofighi Z (Ph.D.) ${ }^{2,3^{*}}$, Motevaseli E (Ph.D.) ${ }^{4^{*}}$, Jafari \\ Nodooshan S (M.Sc.) ${ }^{4}$, Shams Ardekani MR (Ph.D.) ${ }^{1}$
}

\author{
1- School of Pharmacy, International Campus, Tehran University of Medical \\ Sciences, Tehran, Iran \\ 2- Department of Pharmacognosy, Faculty of Pharmacy, Tehran University of \\ Medical Sciences, 14174-14411, Tehran, Iran \\ 3- Medicinal Plants Research Center, Faculty of Pharmacy, Tehran University of \\ Medical Sciences, Tehran, Iran \\ 4- Department of Molecular Medicine, School of Advanced Technologies in \\ Medicine, Tehran University of Medical Sciences, Tehran, Iran \\ *Corresponding authors: Department of Pharmacognosy, Faculty of Pharmacy, \\ Tehran University of Medical Sciences, Tehran 14174-14411, Iran \& Department \\ of Molecular Medicine, School of Advanced Technologies in Medicine, Tehran \\ University of Medical Sciences, Tehran 14176-13151, Iran \\ Tel: +98-21-64121220, +98-21-43052000, Fax: +98-21-89771428 \\ E-mail: ztofighi@tums.ac.ir, e_motevaseli@tums.ac.ir
}

Received: 9 Sep. 2018

Accepted: 20 Feb. 2019

doi: $10.29252 / \mathrm{jmp} .3 .71 .77$

Abstract

Background: Dorema aucheri (Apiaceae) grows in west and southwest of Iran. Young leaves of this plant are used orally as pickle or for cooking some local foods, as well as for the treatment of parasitic digestive infections and constipation.

Objective: The aim of present study was evaluation of cytotoxic potential and total phenols determination of $D$. aucheri young aerial parts extract and fractions and its pickle extract.

Method: The dried powders of $D$. aucheri young aerial parts and pickles were macerated with $80 \%$ methanol and fractionated with petroleum ether (PE), chloroform (CL), ethyl acetate (EA) and methanol (ME). Cytotoxic activity of the total extract, fractions and pickle extract on HT-29, MDA-MB-231, A549, Hela cancer and normal fibroblast cell lines were assessed by MTT assay. Total phenol contents of all samples were determined by Folin-Ciocalteu method.

Results: The potent cytotoxic activities were shown by $P E$ and $C L$ fractions on normal fibroblast cell line with $\mathrm{IC}_{50}$ equal to $17.66 \pm 2.3$ and $48.80 \pm 1.24 \mu \mathrm{g} / \mathrm{ml}$, respectively. Other fractions and extracts didn't have considerable cytotoxic effects on other cell lines. In addition, two mentioen fractions had the lowest total phenols. ME and EA fractions with highest amounts of phenols showed the lowest cytotoxicity.

Conclusion: It is concluded $D$. aucheri compounds have potential to exhibit toxic effects on healthy cells. On the other hand, there is negative correlation between cytotoxicity and phenol contents of $D$. aucheri fractions.

Keywords: Bilhar, Cytotoxic, MTT assay, Phenolics, Umbelliferae 


\section{Introduction}

The Dorema genus belongs to Apiaceae family which consists six species in the flora of Iran [1]. Dorema genus produces an ammoniac gum resin which is known as "Oshagh" in Iranian traditional medicine [2]. The exudate with a warm and dry temperament (mizaj) has been applied for various disorders such as neurotic, urinary, gastrointestinal, respiratory and ophthalmic diseases [3-5].

Dorema aucheri is a perennial endemic species to Iran which grows in high mountains. This herb is locally known as "Bilhar" in coverage areas such as Kohgiluyeh and Boyer-Ahmad and Fars provinces in southwest of Iran [1].

The young aerial parts of the plant are used for pickling (Figure 1) as well as mixing in yogurt in west and southwest regions of Iran. Moreover in folk remedy, the herb is used for treatment of constipation, asthma, bronchitis and parasites of digestive system $[6,7]$.

Previous pharmacological studies exhibited the extract of $D$. aucheri has hypoglycemic [8], anti-hyperlipidemic, antihypercholesterolamic [9], antimicrobial and antioxidant effects [10, 11]. Moreover, phytochemical investigation on this species showed the presence of methoxylated flavones such as salvigenin, nepetin, crisiliol and eupatorin [12]. Previous studies revealed that methylation of flavonoids causes' significant cytotoxicity activity [13].

There are several reports on toxicity and cytotoxic activity of the plants extract [14-16]. Since young aerial parts of $D$. aucheri is used as food in some parts of Iran, the aims of present study was to evaluate cytotoxic activity of total extract and different fractions of dried powdered and pickled $D$. aucheri by MTT assay. In addition, total phenol contents of all mentioned samples were determined.

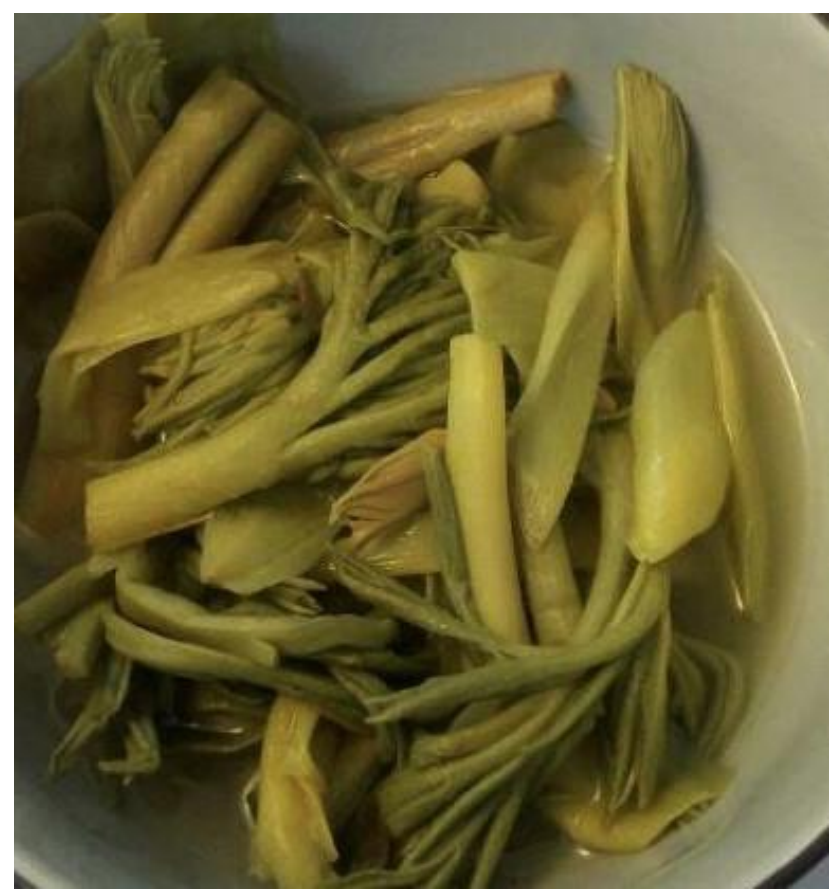

Figure 1- Pickle of Dorema aucheri aerial parts 


\section{Materials and Methods}

\section{Plant Collection}

The young aerial parts of $D$. aucheri were collected from high level of Kohgiluyeh and Boyer-Ahmad Province, southwest of Iran, on March 2015. The plant was identified and authenticated by Professor F. Attar and deposited at Central Herbarium of Tehran University (No. 46056 TUH).

\section{Extraction and fractionation}

Dried powdered of aerial parts and pickled plant of $D$. aucheri extracted by $80 \%$ methanol at room temperature, separately. Both total and pickle extracts were concentrated and lyophilized. The total extract was fractionated with petroleum ether (PE), chloroform (CL), ethyl acetate (EA) and methanol (ME), successively via liquid-liquid extraction.

\section{Evaluation of cytotoxic activity by MTT assay}

Human cancer cell lines including $\mathrm{HeLa}$ cells (Cervical cancer), HT-29 (colon carcinoma), A549 (lung carcinoma) and MDA-MB-231 (breast cancer) and normal fibroblast cell line were purchased from Pasteur Institute, Tehran, Iran. The cells were cultured in RPMI 1640 medium (Biosera, England) supplemented with 10\% FBS and 1\% penicillin-streptomycin. The fibroblast cell line was maintained in Dulbecco's modified Eagle's medium (DMEM Ham's F12; PAA, Germany) supplemented with $15 \%$ FBS and $1 \%$ penicillin-streptomycin.

The cytotoxic activity of samples were assessed using MTT (3-[4, 5-dimethylthiazole2-yl]-2, 5-diphenyltetrazolium bromide) (Sigma-Aldrich, USA) assay. After incubation at $37^{\circ} \mathrm{C}$, all of the cell lines were passaged using trypsinization and one hundred $\mu \mathrm{L}$ of the cells suspension in growth media were incubated into 96-well plates at density of $1 \times 10^{4}$ cells /well. After $24 \mathrm{~h}$, one hundred $\mu \mathrm{L}$ of different concentrations of samples were added to each well. $48 \mathrm{~h}$ later, $20 \mu \mathrm{L}$ of MTT reagent $(5 \mathrm{mg} / \mathrm{ml}$ PBS $)$ were added per well and reincubated for $4 \mathrm{~h}$. The medium were discharged and $100 \mu \mathrm{l}$ of pure DMSO was added to each well. Finally, the absorbance was measured at $570 \mathrm{~nm}$ using a microplate reader (ELX800, BioTek, USA). The mixture of the medium and DMSO was used as negative control. All experiments were conducted in triplicate.

Cytotoxic activities of the samples were expressed as the concentration of sample that produces $50 \%$ of cell growth inhibition $\left(\mathrm{IC}_{50}\right)$ [17].

Selectivity indexes (SI) of various extracts and fractions were calculated by following formula:

$\mathrm{SI}=\mathrm{IC}_{50}$ of sample against normal cells/ $\mathrm{IC}_{50}$ of sample against cancer cells [18].

\section{Determination of total phenols}

Phenolic contents of total and pickle extracts and all fractions were determined by Folin ciocalteau method [19]. In this method, phenols oxidation was occurred in alkaline solution have molybdotungstophosphoric heteropolyanion reagent with yellow color and resultant blue color of molybdotungstophophate was measured. Maximum absorption of blue pigments depends on the phenols composition in the $\mathrm{pH}$ of solutions, obtained by sodium bicarbonate 
Alert for consumption ...

or sodium carbonate [20]. The methanol solution $(0.2 \mathrm{ml})$ of different concentration of each sample and gallic acid were added to 2 $\mathrm{ml}$ of 1:10 diluted Folin-Ciocalteu reagent (with distilled water). Five minutes later, 1.5 ml of saturated sodium bicarbonate solution (60 g/l) was added. Then, after $90 \mathrm{~min}$, the absorption of the solutions were measured at $725 \mathrm{~nm}$ by spectrophotometer. The standard curve of gallic acid (GA) was prepared by various concentration of $0,25,50$ and 100 $\mathrm{mg} / \mathrm{ml}$ and total phenol contents were reported as GAE; Gallic Acid Equivalents (mg of gallic acid/ $g$ of samples).

\section{Statistical analysis}

Results of cytotoxic activity and determination of total phenols were reported as the mean $\pm \mathrm{SD}$ of triplicate experiments and statistical analysis was done by Microsoft Excel 2013.

\section{Results}

\section{Cytotoxic activity}

As seen in Table 1, cytotoxic activity of total and pickle extracts, and different fractions of $D$. aucheri were investigated by MTT assay on HT-29, MDA-MB-231, A549 and Hela cancer cell lines and normal fibroblast cell line. Total extract, CL and PE fractions exhibited moderate cytotoxic activity against colorectal carcinoma with $\mathrm{IC}_{50}$ equal to $184.72 \pm 4.90, \quad 155.68 \pm 5.50$ and $198.53 \pm 1.46$ $\mu \mathrm{g} / \mathrm{ml}$, respectively. $\mathrm{IC}_{50}$ of other fractions and pickle extract were higher than $200 \mu \mathrm{g} / \mathrm{ml}$.

In breast cancer, CL and PE fractions demonstrated significant cytotoxic effect with $\mathrm{IC}_{50}$ equal to $69.7 \pm 2.99$ and $95.38 \pm 2.96 \mu \mathrm{g} / \mathrm{ml}$, respectively. Total extract and ME fraction had moderate cytotoxicity on MDA-MB-231 cell line with $\mathrm{IC}_{50}$ equal to $133.98 \pm 0.01$ and $177.41 \pm 2.63 \mu \mathrm{g} / \mathrm{ml}$, respectively. Pickle extract and EA fraction showed no cytotoxic effect.

Table 1- Cytotoxic activity of total extract, different fractions and pickle extract of Dorema aucheri aerial parts

\begin{tabular}{|c|c|c|c|c|c|c|}
\hline \multirow[b]{2}{*}{ Samples } & \multicolumn{5}{|c|}{$\mathrm{IC}_{50}(\mathrm{SI})$} & \multirow{2}{*}{$\begin{array}{c}\text { Total } \\
\text { Phenols } \\
\text { (GAE/ 100 g } \\
\text { of sample) }\end{array}$} \\
\hline & MDA-MB-231 & A549 & HT29 & Hela & Fibroblast & \\
\hline Total extract & $133.98 \pm 0.007(>1.49)$ & $>200$ & $\begin{array}{c}184.72 \pm 4.90 \\
(>1.08)\end{array}$ & $>200$ & $>200$ & $6.8 \pm 1.75$ \\
\hline PE fraction & $\begin{array}{c}95.38 \pm 2.96 \\
(0.18)\end{array}$ & $>200$ & $\begin{array}{c}198.53 \pm 1.46 \\
(0.08)\end{array}$ & $\begin{array}{c}117.66 \pm 3.01 \\
(0.14)\end{array}$ & $17.00 \pm 2.30$ & $2.8 \pm 0.22$ \\
\hline CL fraction & $\begin{array}{c}69.7 \pm 2.99 \\
(0.7)\end{array}$ & $\begin{array}{c}147.66 \pm 0.23 \\
(0.33)\end{array}$ & $\begin{array}{c}155.68 \pm 5.50 \\
(0.31)\end{array}$ & $\begin{array}{c}145.38 \pm 0.10 \\
(0.33)\end{array}$ & $48.84 \pm 1.24$ & $5.2 \pm 0.11$ \\
\hline EA fraction & $>200$ & $>200$ & $>200$ & $>200$ & $>200$ & $7.7 \pm 0.33$ \\
\hline ME fraction & $\begin{array}{c}177.41 \pm 2.63 \\
(>1.13)\end{array}$ & $>200$ & $>200$ & $>200$ & $>200$ & $12.4 \pm 0.76$ \\
\hline Pickle extract & $>200$ & $\begin{array}{c}171.27 \pm 1.9 \\
(>1.17)\end{array}$ & $>200$ & $>200$ & $>200$ & $3.3 \pm 0.22$ \\
\hline
\end{tabular}

Results are expressed as $\mathrm{IC}_{50}$ value $(\mu \mathrm{g} / \mathrm{ml})$, mean of three determinations \pm standard deviation. PE: Petroleum ether, CL: Chloroform, EA: Ethyl acetate, ME: methanol fraction; SI: selectivity index; HT-29: colorectal, MDA-MB-231: breast, A549: lung, Hela: cervical cancer cell lines 
In lung cancer, pickle extract and CL fraction demonstrated moderate cytotoxicity with $\mathrm{IC}_{50}$ equal to $171.27 \pm 1.9$ and $147.66 \pm 0.23 \mu \mathrm{g} / \mathrm{ml}$, respectively. There were no cytotoxicity observed from other fractions and total extract.

In cervical cancer, only PE and CL fractions demonstrated moderate toxicity with $\mathrm{IC}_{50}$ equal to $117.66 \pm 3.01$ and $145.38 \pm 0.10$ $\mu \mathrm{g} / \mathrm{ml}$, respectively and other fractions and extracts showed no cytotoxicity.

The potent cytotoxic activity were shown by PE and CL fractions on normal fibroblast cell line with $\mathrm{IC}_{50}$ equal to $17.66 \pm 2.3$ and $48.8 \pm 1.24 \mu \mathrm{g} / \mathrm{ml}$, respectively. Other fractions and total extract didn't have any cytotoxic effect on normal cells.

\section{Total Phenol Assay}

Total phenol contents of total and pickle extracts and all fractions of $D$. aucheri were calculated based on $y=0.0065 x+0.0337$, $\mathrm{r}^{2}=0.998$, and reported in Table 1.

It was demonstrated that PE and CL fractions had the lowest amounts of phenols among fractions while ME had the highest phenol contents. The phenol contents of pickle extract was decreased about half of total extract.

\section{Discussion}

All over the world, people used traditional and folklore medicinal plants or herbal drugs in their health care or nutrition programs. The natural consumers believed that the mentioned products are safe but limited researches confirmed health hazards of some considered safe herbal remedies over the previous decades. Recent evidences had shown they could be potentially toxic, carcinogenic and mutagenic [21, 22]. Poisoning from herbal drugs or natural products is often a consequence of incorrect identification and inappropriate preparation or administration, frequently self-administration of them [23, 24].

By technology progress, researchers could assay potential hazardous of herbal medicines. The present study evaluated cytotoxic activity of total extract and different fractions of dried powdered and pickled young aerial parts of Dorema aucheri, which was used as food in west and southwest of Iran.

According to the standard of US National Cancer institute (NCI), herbal extracts with $\mathrm{IC}_{50}$ lower than $20 \mu \mathrm{g} / \mathrm{ml}$ were considered as cytotoxic on cancer cells [25]. Following this criterion, potent cytotoxic effects of PE and CL fractions on normal fibroblast cell line were confirmed which mentioned there are toxic compounds in plant which effect on healthy cells. In addition, the amount of selectivity index (SI) showed selective or nonselective category of cytotoxic compounds. If SI was more than 10 , the cytotoxicity was selective while compounds with SIs between 1-10 were classified as non-selective [25]. In current research, none of extracts and fractions demonstrated selective manner.

A previous study showed methanol extract of aerial parts of $D$. aucheri had considerable cytotoxic effects on HepG2 and A549 cell lines with $\mathrm{IC}_{50}$ equal to 20.09 and $48.65 \mu \mathrm{g} / \mathrm{ml}$, respectively [6]. However, the present study demonstrated total extract and fractions of D. aucheri had no considerable cytotoxicity against A549 lung cancer cell line. Also, there were reports about $D$. aucheri abilities to 
induce necrosis and tumorogenic effects in rats. It was exhibited $D$. aucheri extract in dose of $400 \mathrm{mg} / \mathrm{kg}$ could increase the breast tumor volumes of rats in comparison to groups receiving only DMBA. It was noticeable by consumption of $200 \mathrm{mg} / \mathrm{kg}$ of extract, tumor tissue necrosis was observed [26]. Another study demonstrated injection of $D$. aucheri extract to healthy mice had induced hepatotoxicity as necrosis, inflammation, liver cell proliferation, cholestasis and increase of liver enzymes and bilirubin in a dose dependent manner [16]. Our cytotoxicity results on healthy cells confirmed these reports.

Phenolic compounds from different structures play an important role in fighting against cancers in invitro and invivo models [27]. Present study demonstrated ME and EA fractions of $D$. aucheri with highest amounts of phenols had not considerable cytotoxicity, while PE and CL fractions with lowest amounts of phenolic compounds demonstrated potent toxicity.

\section{Conclusion}

In conclusion, $\mathrm{PE}$ and $\mathrm{CL}$ fractions of D. aucheri extract demonstrated significant cytotoxic effects on breast and normal cell

\section{References}

1. Mozaffarian V. A dictionary of Iranian plant names. Farhang Moaser. Iran. 1996.

2. Izadi $\mathbf{J}$ and Ejlali $\mathrm{R}$. Germination improvement in seeds of gum ammoniac (Dorema ammoniacum). Iran J. Range Des. Res. 2009; 15: 455-63. lines. It is considerable that cytotoxicity of both mentioned fractions on normal cells were higher than cancer cell lines, therefore usage of them in chemotherapy were not appropriated because of their side effects, patient compliance and other factors. The cytotoxic effect of $D$. aucheri on normal cells confirmed that the phytochemical compounds of this plant can induce cancer in healthy persons. Since the aerial parts and pickle of this plant were used as local food in some Provinces of Iran, more studies are proposed on investigation of cytotoxic compounds, evaluation of acute and sub chronic toxicity of plant and its pickle.

\section{Acknowledgment}

The authors gratefully acknowledge Professor Farideh Attar head of the Central Herbarium of Tehran University, who identified the plant. This research was thesis of Pharm D and supported by a grant of School of Pharmacy, International Campus, Tehran University of Medical Science, Tehran, Iran (No. 32369).

\section{Conflict of interest}

The authors declare that there is no conflict of interest

\section{Khorasani A. Makhzan ol-Advieh. Publication and education of Islamic revolution. Iran. 1992, pp: 472-3.}

4. Jorjani S. Zakhire ye Khawrazmshahi. The academy of Medical Sciences of Iran. Iran. 2003, pp: 36-90. 
5. Tonekaboni H. Tohfat ol momenin. Nashre Shahr. Iran. 2007, pp: 283 - 4.

6. Mosaddegh $M$, Esmaeili S, Naghibi F, Hamzeloo Moghadam M, Haeri A, Pirani A and Moazzeni H. Ethnomedical survey and cytotoxic activity of medicinal plant extracts used in Kohgiluyeh and Boyerahmad Province in Iran. $J$. Herbs Spices Med. Plants 2012; 18: 211-21.

7. Rajaei P and Mohamadi N. Ethnobotanical study of medicinal plants of Hezar mountain allocated in south east of Iran. Iran. J. Pharm. Res. 2012; 11: 1153 - 67.
8. Tavana
A, Pourrajab
$\mathrm{F}$,

Hekmatimoghaddam $\mathrm{SH}$, Khalilzadeh $\mathrm{SH}$ and Lotfi MH. The hypoglycemic effect of Dorema aucheri (Bilhar) extract in diabetic type 2 patients: A first clinical trial. Int. J. Pharm. Clin. Res. 2015; 7: 343-7.

9. Ahangarpour A, Teymuri Zamaneh $\mathrm{H}$, Jabari A, Nia HM and Heidari H. Antidiabetic and hypolipidemic effects of Dorema aucheri hydroalcoholic leave extract in streptozotocinnicotinamide induced type 2 diabetes in male rats. Iran. J. Basic Med. Sci. 2014; 17: 808-14.

10. Miraghaee SS and Karimi I. Evaluation of the antioxidant and antimicrobial properties of Dorema aucheri plant. Iran. Red Crescent Med. J. 2012; 14: 684-5.

11. Yazdi FT, Behbahani BA, Vasiee A, Mortazavi SA and Yazdi FT. An investigation on the effect of alcoholic and aqueous extracts of Dorema aucheri (Bilhar) on some pathogenic bacteria in vitro. J. Paramed. Sci. 2015; 6: 58-64.

12. Wollenweber E, Dorr M and Rustiyan A. Dorema aucheri, the first umbelliferous plant found to produce exudate flavonoids. Phytochem. 1995; 38: 1417.
13. Plochmann K, Korte G, Koutsilieri E, Richling E, Riederer P, Rethwilm A, Schreier $P$ and Scheller C. Structure-activity relationships of flavonoid-induced cytotoxicity on human leukemia cells. Arch. Biochem. Biophys. 2007; 460: 1-9.

14. Mirzaei A, Mirzaei $\mathrm{N}$ and Ghavamizadeh M. Antioxidant activity and cytotoxicity of Dorema aucheri by Artemia urmiana: a brine shrimp lethality test. Life Sci. J. 2013; 10: 8-12.

15. Mosaddegh M, Naghibi F, Moazzeni H, Pirani A and Esmaeili S. Ethnobotanical survey of herbal remedies traditionally used in Kohghiluyeh va Boyer Ahmad province of Iran. J. Ethnopharmacol. 2012; 141: 80-95.

16. Mostafavi SH, Fazilati M, Mostafavi SA, Vahhabi MR, Mostafavi F, Omidvarinia S, Zandi-Atashbar N, Derakhshanian $\mathrm{H}$ and Hajipoor AR. Hepatotoxicity of Dorema aucheri (Bilhar) in albino mice. Arch. Iran. Med. 2013; 16: 530-2.

17. Ostad SN, Rajabi A, Khademi R, Farjadmand F, Eftekhari M, Hadjiakhoondi A and Khanavi M. Cytotoxic potential of Centaurea bruguierana ssp. belangerana: the MTT assay. Acta Med. Iran. 2016; 54: 583-9.

18. Goodarzi S, Nateghpour M, Asgharian P, Hadjiakhoondi A, Yassa N, Tavakoli S, Mirzaei J, Farivar L, Motevalli Haghi A and Tofighi Z. Antimalarial and cytotoxic activities of roots and fruits fractions of Astrodaucus persicus extract. Iran. J. Basic Med. Sci. 2017; 20: 1318-23.

19. Goodarzi S, Hadjiakhoondi A, Yassa N, Khanavi $M$ and Tofighi $Z$. Essential oils chemical composition, antioxidant activities and total phenols of Astrodaucus persicus. Iran. J. Basic Med. Sci. 2016; 19: 159-65. 
20. Tofighi Z, Es-haghi A, Maleki Asl M, Tajic AR, Saber Navai M, Tavakoli S, Hadjiakhoondi $A$ and Yassa N. Investigation of chemical keys for relationship between plants and their unifloral honeys by hydrodistillation and SPME and biological activities of honeys. Eur. Food Res. Tech. 2014; 238: 665-73.

21. Fennell CW, Lindsey KL, McGaw LJ, Sparg SG, Stafford GI, Elgorashi EE, Grace $\mathrm{OM}$ and Staden JV. Assessing African medicinal plants for efficacy and safety: pharmacological screening and toxicology. $J$. Ethnopharmacol. 2004; 94: 205-17.

22. Philomena G. Concerns regarding the safety and toxicity of medicinal plants - An overview. J. Appl. Pharm. Sci. 2011; 1: 40-44. 23. Popat A, Shear NH, Malkiewicz I, Stewart MJ, Steenkamp V, Thomson S and Neuman MG. The toxicity of Callilepis laureola, a South African traditional herbal medicine.
Clin. Biochem. 2001; 34: 229-36.

24. Stewart MJ and Steenkamp V. Toxicology of African herbal remedies. South African Ethnobotany 2000; 1: 32-3.

25. Goodarzi S, Tabatabaei MJ, Mohammad Jafari R, Shemirani F, Tavakoli S, Mofasseri $\mathrm{M}$ and Tofighi Z. Cuminum cyminum fruits as source of luteolin-7-O-glucoside, potent cytotoxic flavonoid against breast cancer cell lines. Nat. Prod. Res. 2018; 22: 1-5.

26. Mahdavi Gourabi A, Ostad Rahimi A, Sadeghi H, Afshoon T, Mahdavi R and Afshoon E. The Anti-breast tumors effects of Dorema aucheri plant (Bilhar plant) extract, margins of Zagros Mountains in Iran. Vitae Columbia. 2014; 21: 278-84.

27. Carocho M, Ferreira ICFR. The role of phenolic compounds in the fight against cancer - A review. Anticancer Agents Med. Chem. 2013; 13: 1236-58. 